\title{
Triangular Causality and Controlling Parallel Exchange Market
}

\author{
Bijan Bidabad $^{1}$
}

Abstract

In this paper, the triangular relationship of money, price, and foreign exchange in a causality context are studied. It is concluded that regulating the exchange rate by volume of liquidity in a period of less than a year is not possible, but in annual and biannual analyses we can regulate the exchange rate through controlling the liquidity. In other words, in the long run, the exchange rate is affected by liquidity and price level, but in the short run, the price level has only temporary effects on the exchange rate. The results of the study show that: liquidity affects the exchange rate in the long run; price affects the liquidity in the long run; in the long run, liquidity and exchange rate affect prices.

Our results show that injection of foreign exchange into the parallel exchange market with different lags has little effects with different directions on the exchange rate. The same result is true for the relationship between liquidity and dollar rate. In other words, in spite of the long run relationship between exchange rate and liquidity, we cannot justify this relationship in the short run. The same is true with the balance of payments position and exchange rate in the short run.

By simulating the relationship between injecting (selling) foreign exchange in the parallel exchange market, liquidity and the cumulative balance of payments all with exchange rate, we can conclude that in the short run, regulating exchange rate by instruments such as selling exchange in the parallel market or controlling the liquidity is not possible, but in the long run, conducting foreign exchange sale policy and controlling the liquidity and the balance of payments position can control the exchange market.

Keywords: Foreign exchange, Money supply targeting, Monetary policy, Market control, Exchange rate policy

\section{Introduction}

All policies that are to somehow related to exchange rate control can be related to exchange rate targeting, and most of the economic policies are to somehow related to foreign exchange. But at this moment, we are focused on the supply of foreign exchange for controlling the exchange rate. The generality of this discussion is prevailing in exchange rate management policies, but here we only study the open market policy conducted on foreign exchange by monetary authorities in the parallel market. This policy is called "sale of foreign exchange in the parallel (free) market" and was adopted for the period of 1989 to 2001.

In general, it is clear that whenever governments try to control prices through non-economic measures which are in confliction with supply and demand mechanism, automatically a parallel market is developed. The emergence of the parallel exchange market in the previous two decades is not exempted from this general rule. Governments consider parallel markets as an obstacle for implementing their policies, but we should accept that parallel markets are the results of the government policies. In other words, whenever we do not follow the inherent rules of economics, we should be waiting for the emergence parallel market in the same field of policymaking.

Before the revolution, the foreign exchange parallel market was negligible. Very few amounts of foreign exchange were transacted in exchange offices at a price which followed the exchange rate of the banking system, so these exchange offices pegged their rates between of bid and offer rates of the banking rates. In other words, their

1 (B.A., M.Sc., Ph.D., Post-Doc.) Research Professor of Economics, Monetary and Banking Research Academy, bidabad@yahoo.com bijan@bidabad.com http://www.bidabad.com.

This paper is the summary of the project: Bijan Bidabad, Parallel Exchange Market Control by Monetary Targeting and Complementary Policies. Monetary and Banking Research Academy, Central Bank of Iran, Tehran, Iran. http://www.bidabad.com/doc/exchange-control.pdf

http://www.bidabad.com/_ bijan@bidabad.com_ bidabad@yahoo.com 
bid rate was a little more than the bid rate of the banking system, and their offer rate was a little lower than the banking offer rates. This method of pricing helped them to survive; in other words, their profit margin was between the profit margins of the banks. After the revolution, banks developed regulations on exchange sale, which was considered as a restriction for the supply of foreign exchange. The restricted supply practically pushed up the rates, but the government kept banking rates unchanged, which caused to develop a parallel market with higher rates. Because of the unordinary conditions of post-revolution, the gap between the parallel market and banking rates widened. The government tried several times to control this market with new regulations. The extent of these regulations went so far to consider the dealers of the parallel market as trouble-makers, or economic terrorists and heavy penalties were developed for them, and police and security forces were used against this market, but the government had little success in eliminating this market.

One of the policies applied against this market was government interference in the market by direct sale of foreign exchange in order to increase the supply and decrease the parallel rates. This policy was conducted in several ways so that the banking system also sold foreign exchange with special rates and conditions. Sometimes the central bank gave official permissions to private foreign exchange offices and sold foreign exchange through these offices. In some exceptional cases, the brokers of the central bank sold foreign exchange on the nearby main streets. These decisions were made on the bases of the analysis of the decision makers of those days, but the main principle behind these decisions was injecting foreign exchange into the market in order to decrease the parallel rates and achieve income in Rial terms.

The main precondition for applying this policy is the acceptance of an unofficial foreign exchange market. In some years, the policymakers were so radical that they considered the dealers of the parallel market as smugglers and punished them very severely, which suggests that this policy was not developed very well. We should accept that during the scarcity of foreign exchange supply with fixed rate regime, this is a natural phenomenon, and the market mechanism creates it automatically. The best method of dealing with this market is accepting it for the first time. This means that we should legally accept the transactions through this market and even consider it as an economic activity and prevent any noise from it and in the next phase automatically try to marginalize it by applying policies and adopting reforms in foreign exchange management. If the foreign exchange system tends to unify, the management of the system becomes transparent. In other words, all transactions of goods and services should be done in single rates, and the rate of the parallel market will, at last, be within the margins of official rate fluctuations.

Since the prices of many items of goods and services are affected by the foreign exchange rate in the parallel market and its fluctuations will cause the fluctuation of the prices of goods and services, the stabilization of the foreign exchange rate in the parallel market will cause partial stabilization in goods and services market. The injections of foreign exchange into the parallel market for stabilization will spillover into other markets.

After the revolution in Iran, the volume of money in circulation has had an increasing trend. Economic theories demonstrate that this increase will lead to depreciation of money, in other words, when the volume of Rial is increased, we should expect that the value of Rial is to be reduced against foreign currencies, or its parity rate decreases. We have practically seen this event in the past few decades. The increase of the volume of Rial from 2613 billion in 1996 to 320957 billion Rials at the end of 2001 can be the main cause of the increase of parity rate of American Dollar from 70 Rials to 8000 Rials. Econometric researches also confirm this finding.

The policy of selling foreign exchange in the parallel market not only increases the supply of foreign exchange, but also decreases the amount Rial in the market, both of which will strengthen the national currency. Most of the increases of the amount of liquidity after the revolution have been the result of the expansion of monetary base through the increases of government sector debts to the banking system. The details of this phenomenon have been described in several pieces of research, but here we consider that the mentioned results are sufficient to be used and not to be retested. The increase of the government sector's debt to the banking system has been created through financing budget deficit by borrowing from the banking system, which is similar to seignorage of extra money by expanding the monetary base. The policy of selling foreign exchange in the parallel market can be regarded as a method for partially financing the budget deficit. In this way, the government can finance the budget deficit by selling foreign exchange in the parallel market at unofficial prices without obligation of borrowing from the banking system. In other words, without increasing the liquidity (in spite of borrowing from the banking system), this policy can finance the budget deficit.

Price increase and inflation in Iran has a monetary source. Many studies confirm this hypothesis. The increase in money supply causes an increase in general price level instead of increasing the supply of goods and services in the 
economy. Regarding this concept, it could be said that the policy of selling foreign exchange in the parallel market will decrease the price level through the decreasing foreign exchange rate which causes to decrease the price of imported commodities which use foreign exchange from the parallel market sources, and also through decrease of liquidity which has a deflationary effect.

After the approval of the Usury-Free Banking Law, since bond has usury nature, it cannot be applied as a policy tool for changing the amount of money in circulation. In the western economies, central banks conduct open market operations by buying and selling bonds, and decrease or increase the amount of money in circulation and thereby, affect the interest rates and investment thereafter. But as it was mentioned earlier, since it is not possible to use bonds, it is not possible to conduct open market operations. The government interference in the parallel exchange market affects liquidity, and if the government buys, as well as selling foreign exchange in this market, these activities will be more similar with open market operations, and therefore, it is possible to affect interest rate in the parallel market by applying this policy. Of course, this kind of operation is not completely in accordance with open market operation, but when other monetary instruments are not efficient enough, or applicable, this policy is of great help to monetary authorities.

After this explanation, we return to the policy of selling foreign exchange in the parallel market. This policy confirms the followings:

- The parallel market is implicitly accepted

- It is a step towards exchange rate unification

- It helps to stabilize the rates of foreign exchange

- It decreases the amount of available Rials, and thereof strengthens the national currency

- It can partially finance the budget deficit

- This policy has deflationary effects

- It can be regarded as a monetary tool for open market operations

In the macro-econometric model of $\operatorname{Iran}^{2}$, the effect of selling foreign exchange in the parallel market has been studied. The calculations show that by selling foreign exchange equal to one thousand billion Rials, the exchange rate of the parallel market decline will be 65 Rials.

\section{Time series analysis}

In this section, we test the time series for stationarity, to be used in the next sections. The following variables have been tested for unit root. All data are monthly series. Several tests such as $\mathrm{DF}^{3}$ and $\mathrm{ADF}^{4}$ have been used, and by using correlogram, auto-correlation, and partial correlation, the necessary differences were extracted to make the series stationary. Tests have been carried out on the followings variables:

1. Foreign exchange rate

2. Consumer price index

3. Liquidity (the broad definition of money $\mathrm{M}_{2}$ )

According to the studies, the following table has been prepared which shows the changes for making the stationery of the variables

\section{Variable}

Exchange rate [D(DOLLAR)]

Consumer price index $[\mathrm{D}(\mathrm{CPI})]$

\section{Changes made to make the series stationary}

First order difference

First order difference

Liquidity DLOGM $\mathrm{D}_{212}=\mathrm{D}\left(\log \left(\mathrm{M}_{2}\right), 1,12\right) \quad$ First order difference and 12 months difference on logarithm

After doing changes to make the series stationary, we concluded that:

1. The logarithm of most of the series increases stationarity

2 - Bidabad, 1996. Http://www.bidabad.com/

3 - Dickey-Fuller.

4 - Augmented Dickey-Fuller. 
2. Some monetary series and prices needed 12 months difference

3. Therefore, the following variables can be regarded as $\mathrm{I}(1)$ variables

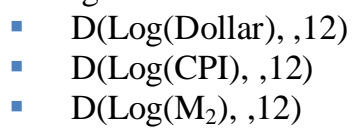

\section{Causality between the main variables}

The previous studies and the assumptions of the present study are based on the tight relationship between monetary variables, foreign exchange rate, and prices. In this section, we use causality tests on these variables. In other words, we want to test the direction of the effect on the foreign exchange rate by the monetary variable and general price level.

By the previous section, we found out the different orders to make the necessary time series stationary. Now we use these results. Before evaluating the causality between the variables, in order to find the correct form of Granger relationship, we have to check for their co-integration.

If the residual of long term regression of the two variables are stationary, or in other words, they have not a unit root, the two variables are co-integrated. If so, their simple difference will not be enough for regression, and therefore, the model should be used as $\mathrm{ECM}^{5}$. Although this correction can explain the short variations of the model around the long term trend by inserting an error item which has been obtained from the long run equation, it adds its own problems to the model. For example, if the specification of the model is not strictly supported by economic theory, the results of the Error Correction Model will have conceptual problems.

\section{Theoretical dynamic causality among variables}

When we define a regression, we implicitly presuppose that what variable or variables explain another variable which is defined as a dependent variable. It means that we define the causality relationship in which, by changing a variable, the dependent variable will change. This causality relationship can be a one-way relationship or two ways. If $\mathrm{X}$ causes $\mathrm{Y}$, but $\mathrm{Y}$ has no effect on $\mathrm{X}$, it is a one-way relationship. But if $\mathrm{X}$ affects $\mathrm{Y}$, and $\mathrm{Y}$ affects $\mathrm{X}$, then we have a two-ways or polar relationship. One of the methods for the causality test is the Granger test. This test is based on this concept that the future cannot affect the past or the present time. The test is a kind of VAR(k) test:

$$
\begin{aligned}
& Y_{t}=\alpha_{10}+\sum_{i=1}^{k} a_{i j} X_{t-j}+\sum_{j=1}^{k} \beta_{1 j} Y_{t-j}+e_{1 t} \\
& X_{t}=\alpha_{20}+\sum_{j=1}^{X} a_{2 j} X_{t-j}+\sum_{j=1}^{K} \beta_{2 j} Y_{t-j}+e_{2 t}
\end{aligned}
$$

Upon the above equations, we can evaluate the following different cases:

1. If $\left\{\alpha_{11}, \alpha_{12}, \ldots, \alpha_{1 k}\right\} \neq 0$ and $\left\{\beta_{21}, \beta_{22}, \ldots, \beta_{2 k}\right\}=0$, there is a one-way causality relationship from $\mathrm{X}$ to Y.

2. If $\left\{\alpha_{11}, \alpha_{12}, \ldots, \alpha_{1 k}\right\}=0$ and $\left\{\beta_{21}, \beta_{22}, \ldots, \beta_{2 k}\right\} \neq 0$, there is a one-way causality relationship from Y to $\mathrm{X}$.

3. If $\left\{\alpha_{11}, \alpha_{12}, \ldots, \alpha_{1 k}\right\} \neq 0$ and $\left\{\beta_{21}, \beta_{22}, \ldots, \beta_{2 k}\right\} \neq 0$, there is a two ways causality relationship between $\mathrm{Y}$ and $\mathrm{X}$.

To test the above hypothesis, we use F statistics. This test will be carried out after testing for stationarity and making variables stationary before further use.

5 - Error Correction Model. 
In order to find the causality relationship between the main variables, the triangle below is important. That is to say, we want to know which of the three variables of the foreign exchange rate, price, and liquidity is the cause of changes in other variables and how deep this effect is and then, find out which variable works as a catalyst.

\section{Foreign exchange rate}

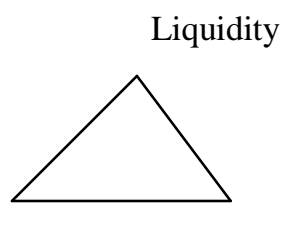

Price level

\section{Triangular Causality}

To solve the model, we explain the triangular causality relationship. We want to know how the three variables, $\mathrm{X}, \mathrm{Y}$, and $\mathrm{Z}$, affect each other. On the basis of previous definitions, we define:

1. One way chain relationship if:
a- $\mathrm{X}$ affects $\mathrm{Y}$
b- $Y$ does not affect $X$
c- $\mathrm{Y}$ affects $\mathrm{Z}$
d- $Z$ does not affect $T$
e- $\mathrm{X}$ affects $\mathrm{Z}$ (through $\mathrm{Y}$ )
f- $Z$ does not affect $Z$

We say that there is a one-way relationship from $\mathrm{X}$ to $\mathrm{Y}$ and to $\mathrm{Z}$ :

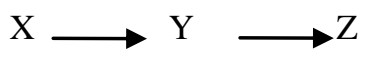

For example, rain $(\mathrm{X})$ increases water $(\mathrm{Y})$, and water grows the plants $(\mathrm{Z})$.

2. Two to one, one-way relationship if:
a- $X$ does not affect $Y$
b- Y affects X
c- $\mathrm{X}$ affects $\mathrm{Z}$
d- $Z$ does not affect $X$
e- $Y$ affects $Z$
f- $Z$ does not affect $Y$

We say both $\mathrm{X}$ and $\mathrm{Y}$ affect $\mathrm{Z}$ :

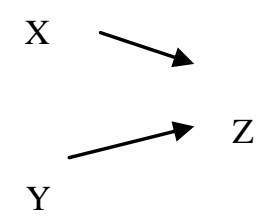

For example, rain $(\mathrm{X})$ and sunshine $(\mathrm{Y})$ cause plants $(\mathrm{Z})$ grow.

3- Causality relationship with, or without catalyst, if: 

a- X affects $Y$
b- Y does not affect $\mathrm{X}$
c- Y affects $\mathrm{Z}$
d- Z does not affect Y
e- X affects Z (with, or without catalyst)
f- $\mathrm{Z}$ does not affect $\mathrm{Z}$

We say that there is a one-way relationship from $\mathrm{X}$ to $\mathrm{Y}$ and $\mathrm{Z}$. That is to say:

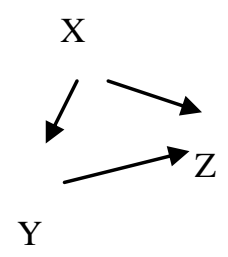

For example, rain $(\mathrm{X})$ causes the growth of plants $(\mathrm{Z})$ and increase of humidity $(\mathrm{Y})$, and humidity (Y) also helps the growth of plants.

4- Annular causality relationship, if:
a- X affects Y
b- Y does not affect $\mathrm{X}$
c- Y affects $\mathrm{Z}$
d- Z does not affect Y
e- X does not affect $\mathrm{Z}$
f- $Z$ affects $X$

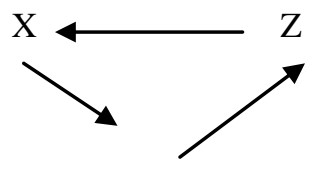

Y

For example, income $(\mathrm{X})$, causes investment $(\mathrm{Y})$ and investment $(\mathrm{Y})$ creates employment $(\mathrm{Z})$, and employment again creates more income $(\mathrm{X})$.

5- Annular one-way causality relationship with partial feedback, if:
a- X affects Y
b- Y does not affect $\mathrm{X}$
c- Y affects Z
d- Z affects Y 
e- $\mathrm{X}$ affects $\mathrm{Z}$ (indirectly)

f- $\mathrm{Z}$ does not affect $\mathrm{X}$

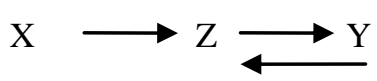

6- Annular causality relationship with complete feedback, if:
a- $\mathrm{X}$ affects $\mathrm{Y}$
b- Y affects $\mathrm{X}$
c- $\mathrm{Y}$ affects $\mathrm{Z}$
d- $\mathrm{Z}$ affects $\mathrm{Y}$
e- $\mathrm{X}$ affects $\mathrm{Z}$ (indirectly)
$\mathrm{f}-\mathrm{Z}$ does not affect $\mathrm{X}$ (indirectly)

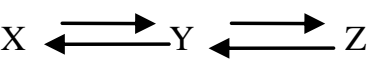

For example, humidity (X) causes plants $(\mathrm{Y})$ to grow, and the growth of plants causes the increase of humidity (X). But the growth of plants $(\mathrm{Y})$ creates natural fertilizer $(\mathrm{Z})$, and fertilizer causes more growth of plants $(\mathrm{Y})$, and the creation of natural fertilizer also directly increases the humidity $(\mathrm{Z})$.

7- The causality effect of one to two with one feedback, if:

a- $\mathrm{X}$ affects $\mathrm{Y}$

b- $Y$ does not affect $X$

c- $\mathrm{Y}$ affects $\mathrm{Z}$

d-Z affects $Y$

e- $X$ affects $Z$

f- $\mathrm{Z}$ does not affect $\mathrm{X}$ (directly)

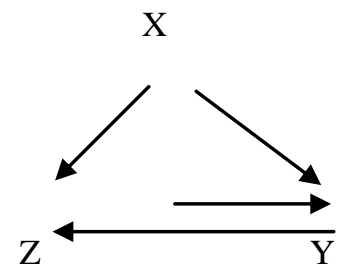

8- Causality effect of one on two (with two feedbacks), if:
a- $\mathrm{X}$ affects $\mathrm{Y}$
b- Y affects $\mathrm{X}$
c- $\mathrm{Y}$ affects $\mathrm{Z}$
d- $\mathrm{Z}$ affects $\mathrm{Y}$ 
e- $\mathrm{X}$ affects $\mathrm{Z}$ (directly)

f- $\mathrm{Z}$ does not affect $\mathrm{X}$ (directly)

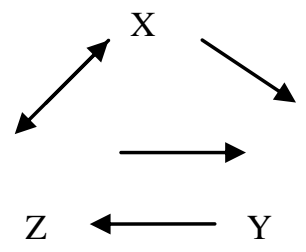

9- Annular causality effect with one feedback, if:
a- $\mathrm{X}$ does not affect $\mathrm{Y}$ (directly)
b- Y affects $\mathrm{X}$
c- $\mathrm{T}$ does not affect $\mathrm{Z}$ (directly)
d- $\mathrm{Z}$ affects $\mathrm{Y}$
e- $X$ affects $Z$ (directly)
f- Z affects X (directly)

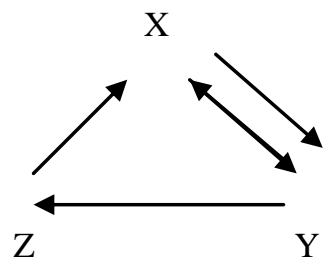

10- Annular causality with complete feedback, if:
a- X affects $Y$ (direct and indirectly)
b- Y affects $\mathrm{X}$ (direct and indirectly)
c- $\mathrm{Y}$ affects $\mathrm{Z}$ (direct and indirectly)
d- Z affects $Y$ (direct and indirectly)
e- $\mathrm{X}$ affects $\mathrm{Z}$ (direct and indirectly)
f- $\mathrm{Z}$ affects $\mathrm{X}$ (direct and indirectly)

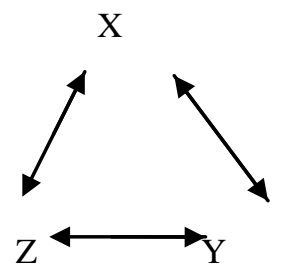




\section{The dynamic causality among variables (practical)}

Regarding the mentioned cases in the previous section, by using the Granger causality test, we test the variables two by two and with different lags. The first group of tests includes testing causality among three variables in a range of 1 to 24 lags:

- The first order difference of Dollar rate series with 12 months seasonal adjustment (dollar)

- The first order difference of liquidity with 12 months of seasonal adjustment (dm2112)

- The first order difference of consumer price index with 12 months seasonal adjustment (dcpi112)

The second group of tests is similar to the first group with one difference that the logarithms of variables are used instead of the original ones.

The summary of the results of these tests is presented in the next tables and diagrams. The table of $\mathrm{F}$ statistics defines the probability of accepting the null hypothesis. This hypothesis is defined as follows:

$\mathrm{H}_{0}$ : The variable one is not the cause of the second variable.

$\mathrm{H}_{1}$ : The variable one is the cause of the second variable.

If the calculated $\mathrm{F}$ is greater than $\mathrm{F}$ in the table, we reject the null hypothesis, and if the calculated $\mathrm{F}$ is smaller than $\mathrm{F}$ in the table, we accept the null hypothesis.

The following table gives F statistics for a large number of observations (more than 120 in this case) and the degree of freedom of the denominator equal to 5 percent and 1 percent level of significance:

F statistics for a number of observations over 120 and degree of freedom of numerator (lag)

\begin{tabular}{lcccccccccccccc}
\hline Lags & $\mathbf{1}$ & $\mathbf{2}$ & $\mathbf{3}$ & $\mathbf{4}$ & $\mathbf{5}$ & $\mathbf{6}$ & $\mathbf{7}$ & $\mathbf{8}$ & $\mathbf{9}$ & $\mathbf{1 0}$ & $\mathbf{1 2}$ & $\mathbf{1 5}$ & $\mathbf{2 0}$ & $\mathbf{2 4}$ \\
\hline $\begin{array}{l}5 \% \\
\text { significance } \mathrm{F}\end{array}$ & 3.84 & 3.00 & 2.60 & 2.37 & 2.21 & 2.10 & 2.01 & 1.94 & 1.88 & 1.83 & 1.75 & 1.67 & 1.57 & 1.52 \\
\hline $\begin{array}{l}1 \% \text { level of } \\
\text { significance F }\end{array}$ & 6.63 & 4.61 & 3.78 & 3.32 & 3.02 & 2.80 & 2.64 & 2.51 & 2.41 & 2.32 & 2.18 & 2.04 & 1.88 & 1.79 \\
\hline
\end{tabular}

By considering the next tables and the graphs for a simple non-logarithmic model, we conclude:

1- The change in Dollar rate, after at least 1 month, will lead to a change in liquidity.

2- The change in liquidity will affect Dollar rate after 1 month, and its further effects appear after 9 to 11 months and again after 2 years changes the Dollar rate.

3- Changes in prices affect liquidity after a lag of 8 months to 2 years.

4- Liquidity changes will affect prices after 1 year.

5- Price changes affect the Dollar rate after 1 month.

6- Changes in Dollar rate affect CPI in every lag.

In short, with the analysis of the above conclusions, at $95 \%$ of significance level, we can draw the following diagram: 
With 3 to 5 months lag
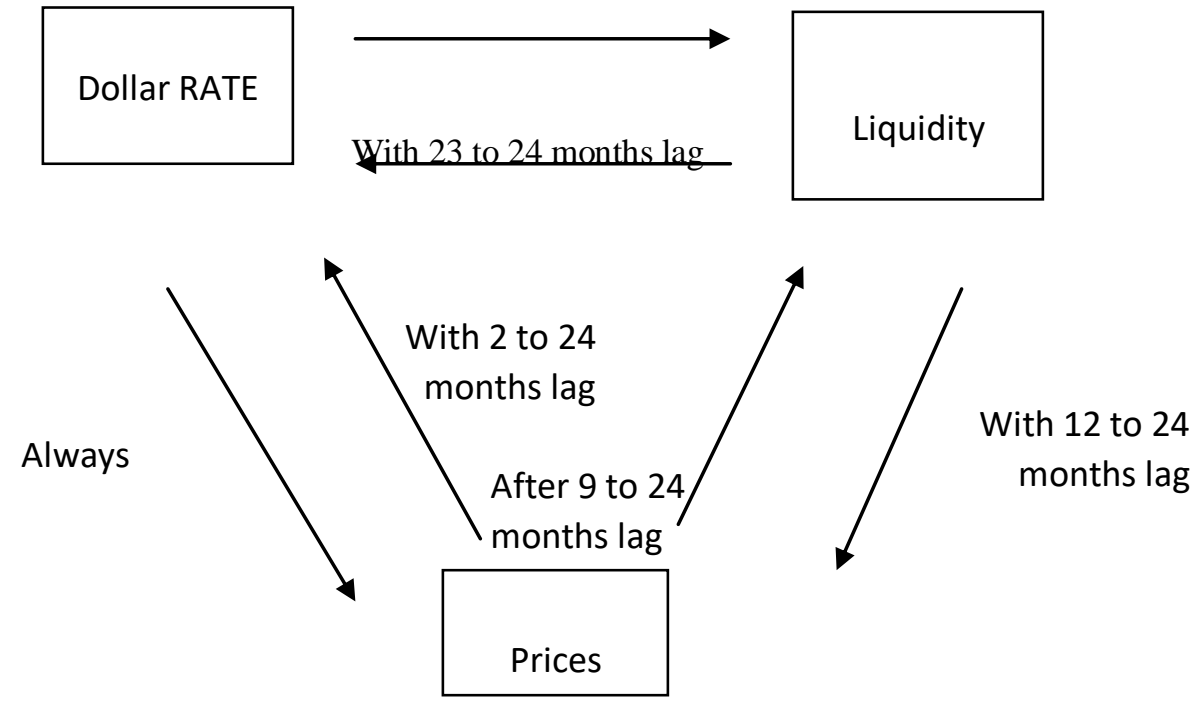

The same study regarding the logarithms of the variables gives the following conclusions:

1- Change of Dollar rate affects liquidity after 3 to 5 months.

2- Change of liquidity does not affect the Dollar rate.

3- Price changes after 3 months affect liquidity.

4- Liquidity change does not affect prices.

5- Price changes after 6 to 11 months and also after 13 to 15 months causes changes in the Dollar rate.

6- Changes in Dollar rate causes changes in prices after 11 months.

In short, the above conclusions can be shown at a $95 \%$ level of significance in the diagram below

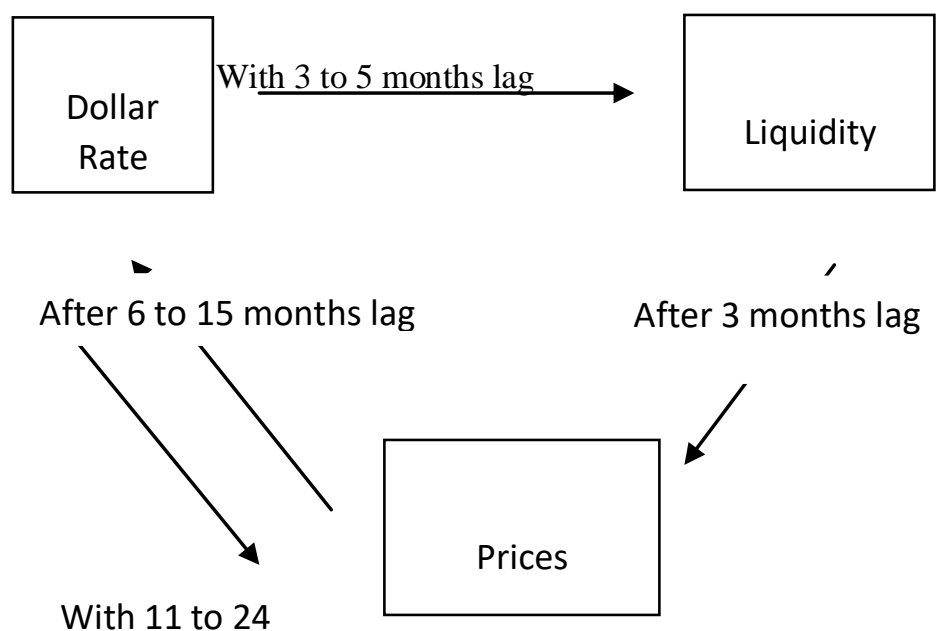

months lag 
Adding up the above results, we can draw the following diagram for short term analysis:

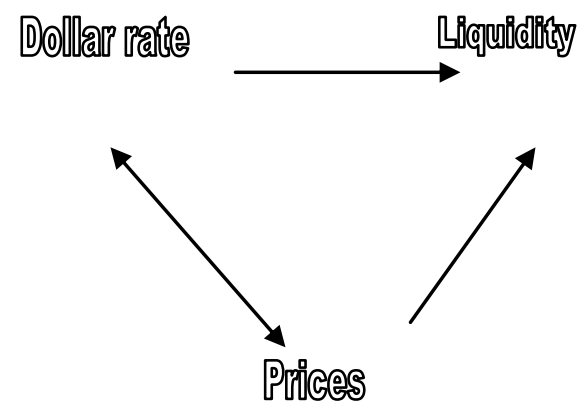

The following diagram is for more than a year analysis:

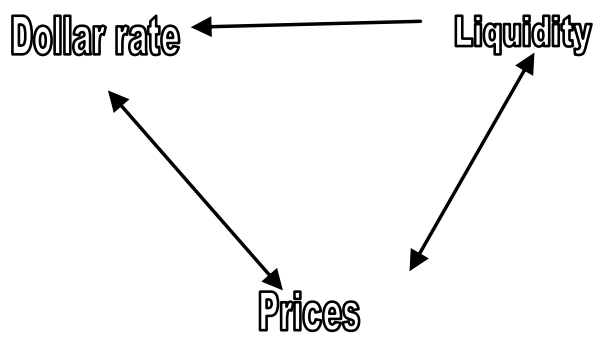

The above diagrams show that foreign exchange rate cannot be regulated by changing liquidity in less than a month, and the results show that only the general price level can affect this variable. But in one to two years of analysis, the foreign exchange rate can be regulated by liquidity control. In other words, the long run trend of the foreign exchange rate is affected by liquidity and price level changes, but since price changes have also short term effects on the foreign exchange rate, therefore, we can change this hypothesis in error correction model as follows:

Foreign exchange rate $=$ long term function (price level, liquidity) + error

If in the first order stationary condition of the three variables of the foreign exchange rate, liquidity, and price level, the co-integrated regression creates stationary error, we follow the error correction model.

After the study of the foreign exchange rate, liquidity, and price index variables and making them stationary, we follow the model with stationary variables. With the estimation of long-run function, we realized that the existing co-linearity between liquidity and CPI, practically the obtained weights are not as they were expected and therefore, it is not possible to follow error correction model. On the basis of obtained graphs and results for long-run effects, we consider the three following relationships:

$\mathrm{EQ} 1:$ DOLLAR $=\mathrm{C}(1) * \mathrm{M} 2+\mathrm{C}(2) * \mathrm{DUMMY} 8000+\mathrm{C}(3) * \mathrm{DUMMY} 8000 * \mathrm{M} 2+\mathrm{C}(4)+$ reseq1

EQ2: $\mathrm{M} 2=\mathrm{C}(11) * \mathrm{CPI}+\mathrm{C}(12)+\mathrm{C}(13) * \mathrm{DUMMY} 8000+\mathrm{C}(14) * \mathrm{DUMMY} 8000 * \mathrm{CPI}+$ reseq 2

EQ3: $\mathrm{CPI}=(\mathrm{C}(21)+\mathrm{C}(22) * \mathrm{DUMMY} 8000) * \mathrm{DOLLAR}+(\mathrm{C}(23)+\mathrm{C}(24) * \mathrm{DUMMY} 8000) * \mathrm{M} 2$ $+\mathrm{C}(25)+\mathrm{C}(26) * \mathrm{DUMMY} 8000+$ reseq3

These equations show the mathematical causality relationship between our variables. Regarding the existence 
of high co-linearity between liquidity and price level, the price variable has been omitted from the first equation. In order to consider the policies for fixing Dollar rate at 8000 Rials, the dummy variable "dummy 8000 " has been introduced into the model which affects the intercept, as well as the slope. The amount of this dummy from the $11^{\text {th }}$ month of 1998 and afterward is one, and for other times is zero.

In order to study the co-integration and concluding whether the mentioned relationships are long term relationships or not, we regress the first order difference of the residuals of each regression to its own lag. In this way, we conduct the unit root test. The results of these tests with the study of MacKinnon show that all three equations have long term nature. In other words:

- Liquidity affects the foreign exchange rate in the long run.

- Prices affect liquidity in the long run.

- In the long run, both liquidity and Dollar rate affect prices.

\section{Selling foreign exchange}

One of the variables which have not been used here is the selling of foreign exchange in the parallel market. As it was mentioned, the application of this policy can affect the monetary and exchange sectors of the economy. Unfortunately, the monthly data for this variable is not available; the annual data as budget information is available in the central bank reports. These figures have been presented in the previous sections of this paper. Studies show the relationship between this variable and the foreign exchange rate in the parallel market. The Macro-econometric model of $\operatorname{Iran}^{6}$ shows that there is a significant relationship between selling foreign exchange in the parallel market and Dollar rate in that market. The following relationship has been defined in that model:

Dollar rate $=\mathrm{f}$ (selling exchange in parallel market, liquidity, cumulative balance of payments)

The above study showed that it is not possible to find a significant relationship for the above function in the short run, even though this function is statistically satisfactory. The reason for that is perhaps the lack of monthly data series of selling foreign exchange for a long period. As it was mentioned, there is a long term relationship between these variables; a concrete short-run relationship has not been found. The cross-correlogram below shows: selling foreign exchange with different lags has little effects with different directions on the parity rate of Rial. The next graph shows the same conclusion for the relationship between liquidity and Dollar rate. In other words, in spite of the existence of the relationship in the long run, it is not possible to define such a relationship in the short run. The same is understood for the position of balance of payments and the foreign exchange rate in the short run.

\section{Conclusion}

In this paper, our goal was to find out the effects of changes in Money on the foreign exchange rate in the short run and long run. In other words, we were looking to find out if we can change foreign exchange rate by changing the liquidity? On the other hand, what is the effect of the price, which has an important catalyst role in this interaction? Therefore, we looked for the triangular relationship between money, prices, and foreign exchange rate, through which we can reach foreign exchange rate control policies.

Calculations show that regulating foreign exchange rate by changing the amount of liquidity for a period of less than one year is not possible, and only the general level of prices can affect this variable. But in annual and biannual analysis, we can say that the control of the foreign exchange rate can be achieved through changes in liquidity. In other words, the long run trend of the foreign exchange rate is defined by liquidity and price level, but prices have also short term effect on the Dollar rate.

In the co-integration analysis, we checked whether the above relationships are credible for the long run or not. We concluded that:

- Liquidity affects Dollar rate in the long run

- Prices affect liquidity in the long run

- In the long run, liquidity and Dollar rate affect the price level

The long-run analysis with annual data shows that there is a significant relationship between selling foreign exchange in the parallel market. In other words, the Dollar rate is a function of the cumulative balance of payments, liquidity, and the amount of Dollar sold in the parallel market. The short-run analysis of the relationships shows that

6 - Bidabad, 1996. http://www.bidabad.com/ 
we cannot find a statistically significant relationship in this regard. In other words, there is only a long-run relationship between the variables, and there is not a clear short term relationship for them. The studies show that selling Dollars in the market with different lags have small effects on the Dollar rate in volatile directions. The same is true with the relationship of Dollar rate and liquidity. That is to say, in spite of the existence of a long-run relationship between Dollar rate and liquidity, we cannot find this relationship for the short run. The same is true for the relationship between the balance of payments and liquidity in the short run.

By simulation of the amount of foreign exchange sold in the parallel market, liquidity, and cumulative balance of payments with Dollar rate, we can conclude that controlling foreign exchange rate in the short run by using tools such as selling foreign exchange in the parallel market or controlling the liquidity is not possible, but in the long run, by the policy of selling foreign exchange and controlling the liquidity and the balance of payments, we can control the foreign exchange market.

\section{References}

Bidabad, Bijan, General monetary equilibrium. Lap Lambert Academic Publishing, OmniScriptum GmbH \& Co. KG, ISBN: 978-3-659-54045-5, Spring 2014.

Bidabad, Bijan, Parallel Exchange Market Control by Monetary Targeting and Complementary Policies. Monetary and Banking Research Academy, Central Bank of Iran, Tehran, Iran, 2007. http://www.bidabad.com/doc/exchange-control.pdf

Bidabad, Bijan, and N. Kalbasi Anaraki, Inflation Targeting: Case Study of Iran, Paper prepared for the Second Hallescher workshop. http://www.bidabad.com/

R- MacDonald (1988), floating Exchange rates, theories and evidence, Unwin Hyman Ltd.

Bernanke, B.S., Laubach, T., Mishkin, F.S. and Posen A.S. (1999), "Inflation Targeting" Princeton: Princeton University Press.

Kumhof, M. Li, S. and Yan, I. (2001), "Balance of payments Crises under Inflation Targeting” Mimeo, Stanford University.

Mishkin, F.S. and Schmidt-Hebbel, K. (2001) "One Decade of Inflation Targeting in the World: What Do We Know and What Do We Need to Know?", NBER 8397.

Ryan, C. and Thompson, C. (2000), "Inflation Targeting and Exchange Rate Fluctuations in Australia" Reserve Bank of Australia, Research Discussion Paper 2000-06.

Jonas, J.; F.S.Mishkin (2003)"Inflation targeting in transition countries: experience and prospects. National Bureau of Economic Research, Working Paper 9667. April. Http://www.nber.org/papers/w9667/.

Bernanke, B.S. and F.S. Mishkin," Inflation Targeting: A New Framework for Monetary Policy, Journal of Economic Perspectives, 1997.

Bernanke Ben S., Laubach, Thomas, Mishkin Fredric S. and Posen Adam S. " Inflation Targeting: Lessons from the International Experience. Princeton, NJ: Princeton University Press.

Christiano, Lawrence J., Martin Eichenbaum; Charles L. Evans, "Identification of the Effects of Monetary Policy Shocks," in M.I. Blejer et al. eds, Financial Factors in Economic Stabilization and Growth. New York, Cambridge University Press, 1996.

Mishkin Frederic S., "Issues in Inflation Targeting "in Price Stability and the Long-run Target for Monetary Policy, Bank of Canada, Ottawa, Canada, 2001.

\section{Copyrights}

Copyright for this article is retained by the author(s), with first publication rights granted to the journal. This is an open-access article distributed under the terms and conditions of the Creative Commons Attribution license (http://creativecommons.org/licenses/by/4.0/) 